\title{
A költség - haszon elv stratégiája Tudomány határok nélkül - brazil hallgatók Magyarországon
}

\author{
Fenyves Veronika ${ }^{a}$ Kovács Barnabás ${ }^{b}$ - Böcskei Elvirac \\ 'Debreceni Egyetem, ${ }^{b}$ Európai Tudományos Oktatási és Kutatási Intézet, \\ ‘Budapesti Müszaki és Gazdaságtudományi Egyetem
}

\section{A TANULMÁNY CÉLJA}

A brazil kormány létrehozta a Tudomány Határok Nélkül ösztöndíjprogramját, amelynek keretében a hallgatóknak lehetővé tették, hogy felsőfokú tanulmányaik során egy évet külföldi egyetemeken tanulhassanak. A programhoz Magyarország a közép-európai országok közül elsőként csatlakozott, így a magyar felsőoktatási intézmények kínálata a legnagyobb országok egyetemeinek ajánlatai mellett jelent meg. A jövőre vonatkozóan meghatározónak tartottuk, hogy megismerjük, hogy hogyan látnak minket, magyarokat a külföldröl érkezők, milyennek ítélik meg oktatási rendszerünket, mennyiben felel meg nemzetközi szinten oktatásunk struktúrája, színvonala, melyek az erősségeink, és melyek azok a területek, amelyek még kihívásokban bővelkednek.

\section{ALKALMAZOTT MÓDSZERTAN}

A tanulmány első részében a Tudomány Határok Nélkül ösztöndíjprogram ismertetésére kerül sor. Ezt követően a szakirodalmi feldolgozás keretében a nemzetközi hallgatói mobilitás három pólusának - a Csendes óceániai, Ibériai, közép-európai pólus - főbb jellemzőire térünk ki. A kérdőíves felmérés témaköreinek ismertetését követően kerül sor a kapott eredmények bemutatására. A kérdőív feldolgozása SPSS-es statisztikai adatelemzéssel történt.

\section{LEGFONTOSABB EREDMÉNYEK}

Jelen cikkben a Magyarországon tanulmányokat folytató brazil hallgatók megélhetési költségeinek ismertetésére kerül sor. A költségek elemzésén keresztül többek között választ kaptunk arra a kérdésre, hogy a hallgatók számára nyújtott ösztöndíj fedezetet teremtett szükségleteik kielégítésére. Kutatási eredményeink alátámasztották feltételezésünket, amely szerint a hallgatók prioritásként kezelik, hogy kedvezőbb anyagi feltételekkel tudjanak tanulni, így a képzés választásában szerepe volt az ösztöndíj lehetőségének, továbbá a megélhetési költségeknek.

\section{GYAKORLATI JAVASLATOK}

Az oktatás finanszírozása a világ valamennyi országába egy hosszú távú befektetés, amelynek megtérülése csak számokban nem, vagy legalábbis nehezen mérhető. A pénzben mérhető profiton túl a nemzetközi mobilitásnak sokkal nagyobb értéket kell, hogy képviseljen, olyan értékeket, mint a nyitottságot és megértést a különböző kultúrák megismerése révén, a kritikus gondolkodásmód kialakítását, a készségek fejlődését. A külföldi tanulmányok választása egy igen összetett folyamat, így a hallgatói mobilitás mozgatórugóinak feltérképezése a továbbiakban is számos kutatási területnek adhat teret.

Kulcsszavak: hallgatói mobilitás, felsőoktatás, Tudomány Határok Nélkül ösztöndíjprogram, megélhetési költség

Köszönetnyilvánitás: A kutatás a „Magyarországon tanulmányokat folytató külföldi hallgatók értékközvetitö szerepe, stratégiai jelentőségük a felsőoktatás nemzetközivé válásában" c. projekt keretében valósult meg. A kutatást a Pallas Athéné Geopolitikai (PAGEO) Alapítvány támogatta. A szerzők köszönetüket fejezik ki a Magyar Rektori Konferencia munkatársainak a kérdőívek kiküldésében nyújtott segítségükért.

DOI: https://doi.org/10.15170/MM.2019.53.07.07 


\section{BEVEZETÉS}

A Tudomány Határok Nélkül nemzetközi ösztöndíjprogram révén a brazil hallgatók számára megnyílt a lehetőség arra, hogy egy távoli nemzet felsőoktatási rendszerét, kultúráját megismerhessék. A nemzetközi program egyik fogadó országaként Magyarország számára is új kihívásokat, és egyben új lehetőségeket is jelentett a kétoldalú kapcsolat. A fogadó egyetemek polgárai, oktatók, kutatók, hallgatók egyaránt betekintést nyerhettek a brazil kultúra sokszínűségébe, ugyanakkor Magyarország is megmutathatta multikulturális környezetét. A jövőre vonatkozóan meghatározónak tartottuk, hogy megismerjük, hogy hogyan látnak minket, magyarokat a külföldröl érkezők, milyennek ítélik meg oktatási rendszerünket, mennyiben felel meg nemzetközi szinten oktatásunk struktúrája, színvonala, melyek az erősségeink, és melyek azok a területek, amelyek még kihívásokban bővelkednek. A primer kutatás során vizsgáltuk a brazil hallgatók motivációit, értékközvetítő szerepüket és nem utolsó sorban a nemzetgazdaságra gyakorolt hatásukat.

Ma már a világ valamennyi térségében felismerték a hallgatói mobilitásban rejlő lehetőségeket. A brazil kormány 2012-ben létrehozta a Tudomány Határok Nélkül ösztöndíjprogramját, amelynek keretében a hallgatóknak lehetővé tették, hogy felsőfokú tanulmányaik során egy évet külföldi egyetemeken tanulhassanak. Elsősorban a természet- a müszaki- az informatikatudományok, az orvos- és egészségtudományok területén tanulmányokat folytató hallgatóik élhettek a pályázati lehetőséggel. Az alapképzésben részt vevők mellett a doktori $(\mathrm{PhD})$ képzésben részt vevők számára is biztosították a nemzetközi ösztöndíjprogramban való részvétel lehetőségét.

A programhoz Magyarország 2012-ben, a közép-európai országok közül elsőként csatlakozott, így a magyar felsőoktatási intézmények kínálata a legnagyobb országok egyetemeinek ajánlatai - Amerikai Egyesült Államok, Kanada, Japán, Egyesült Királyság, Németország, Franciaország, Olaszország, Spanyolország, Portugália, Hollandia - mellett jelent meg.

\section{IRODALMI ÁTTEKINTÉS}

A nemzetközi hallgatói mobilitás három pólusa a Csendes óceániai csoport (az Egyesült Államok, az Egyesült Királyság, Ausztrália és Új-Zéland); a közép-európai pólus (közép- és nyugat-európai országok) és az ibériai pólus (Franciaország, Spanyolország és Portugália) - közül a közép-európai pólus egy kis országára, Magyarországra fókuszáltunk.

Számos publikáció foglalkozik a nemzetközi hallgatói mobilitás kérdésével, kutatva azt, hogy melyek azok a tényezők, amelyek befolyásolják a hallgatók azon döntéseit, hogy külföldön szerezzenek diplomát (Leung 2013, Brooks \& Waters 2011, Hetesi és Kéri 2018). A motivációk ugyan egyénenként eltérőek, azonban a pólusok egyedi dominanciái meghatározóak a külföldi tanulás szempontjából.

A Csendes óceániai térség piaci dominanciája töretlen, ugyanis számos külföldi diák részére a világ legnevesebb egyetemein való tanulás egy olyan befektetés, amelyért képesek komoly anyagi áldozatokat is hozni (Börjesson 2017). Az Egyesült Államok, az Egyesült Királyság és Ausztrália felsőoktatási intézményei fogadják a világon a legtöbb külföldi hallgatót. A gazdasági és politikai erőfölény mellett a magas szintü, kiemelkedő oktatási és tudományos tevékenység az - a világ felsőoktatási intézményeinek rangsorában való vezető pozíciójuk évtizedek óta töretlen -, amely egyben magyarázatot ad arra, hogy miért ezekbe az országokba érkeznek a legtöbben, amennyiben külföldön szeretnének diplomát szerezni.

A másik két pólusra érkezők esetében elsősorban a történelmi gyökerek (az ibériai pólus esetében a gyarmati országok dominanciái figyelhetők meg), továbbá a kismértékủ földrajzi távolságok (közép-európai országok) voltak azok, amelyek komoly befolyásoló tényezővel bírtak abban az esetben, ha az otthoni továbbtanulással szemben, a hallgató külföldi diploma megszerzését részesítette előnyben (Börjesson 2017).

A közép-európai pólus esetében a bolognai folyamat ${ }^{1}$ elősegítette, hogy a kisebb európai országok is bekapcsolódjanak a nemzetköziesedés folyamatába. Ez elsősorban a rövidtávú (egy-két féléves) programokon való részvételt jelenti, amelynek keretében ösztöndíjjal tudnak a hallgatók egy-egy félévet egy másik országba tanulással eltölteni. Nemzetközi szinten a bolognai folyamat egyértelmüen pozitív hatással volt a mobilitási csereprogramokra, új lehetőségeket teremtett e területen. Amikor a bolognai rendszer bevezetésre került, azzal elsősorban az Európán belüli hallgatói mobilitás volt a fö célkitüzés.

\footnotetext{
1 1999. június 19-én 29 európai ország oktatási miniszterei aláírták az ún. Bolognai Nyilatkozatot.((http:// www.bologna-bergen2005.no/Docs/00 Main_doc/990719BOLOGNA_DECLARATION.PDF)
} 
A határokon átnyúló programok, a hallgatói, az oktatói, és a kutatói kapcsolatok erősítését szolgálta. A közös, idegen nyelvü képzések biztosítása volt az első lépés ahhoz, hogy a Leuveni nyilatkozatban $^{2}$ deklarált elvek majdan teljesülhessenek. Ma már elmondhatjuk, hogy a bolognai folyamat bevezetése óta a határok nélküli hallgatói mobilitás Európában megvalósult. Európa azonban nemcsak a „szüken” vett európai térségből érkező fiatalok számára nyitott, hanem a távoli kontinensröl érkezőket is örömmel fogadja. A távoli kontinensek közötti nemzetközi együttmüködés egyik sikertörténete volt a Magyar Rektori Konferencia által koordinált, a brazil állam által támogatott Tudomány Határok Nélküli ösztöndíjprogram.

\section{A KUTATÁS MÓdSZERTANA}

A kérdőíves kutatás célja az volt, hogy feltárja azokat a lehetőségeket, amelyek alapján - a hazájukon kívül tanulmányokat folytatni kívánó fiatalok - Magyarországot, mint lehetséges célországot jelölik meg.

A kérdöív kitöltésére vonatkozó felhívásunkat valamennyi Magyarországon tanulmányokat folytató, a Tudomány Határok Nélkül nemzetközi ösztöndíjprogram kedvezményezettje részére kiküldtük. A kutatás során a kérdőíves adatfelvételre papír alapon és online formában került sor. A kérdőív a hallgatók anyanyelvén (portugálul) és angolul volt elérhetö. Az adattisztítást követően az elemzésre alkalmas kérdőívek száma 567 db volt, amely a - Magyarországon tanulmányokat folytató - brazil hallgatók 26 százalékát (567/2187) tette ki. A viszonylag magas kitöltöttségnek köszönhetően a reprezentativitás - nem csak országosan, hanem intézményi szinten, továbbá képzési területenként is - biztosított volt. A kérdőív feldolgozása az SPSS programmal, statisztikai adatelemzéssel történt.

A brazil programban részt vevők esetében a kérdőív négy nagy témakört érintett, és a témakörökön belül 10-18 részterületet vizsgáltunk. A kutatás során, a kérdőíves felmérés keretében arra kerestük a választ, hogy:
- Mely tényezők játszottak szerepet abban, hogy a külföldi hallgatók hazájukon kívül folytassanak tanulmányokat?

- A választott képzéssel, az oktatásszervezéssel, továbbá az intézményi szolgáltatásokkal mennyiben voltak elégedettek, másrészt a képzés befejezését követően melyek a jövőbeni terveik?

- A képzési, megélhetési költségek alakulására vonatkozóan milyen előzetes információkkal rendelkeztek, az ösztöndíj által nyújtott finanszírozás mellett szükség volt-e egyéb kiegészítő forrásokra? Hogyan alakultak a megélhetési költségeik?

- Hogyan alakult a szabadidő és a tanulás aránya, a szabadidő eltöltésének milyen lehetőségei voltak, illetve voltak-e korlátozó tényezők?

Jelen cikkben - a terjedelmi korlátokra való tekintettel - a Magyarországon tanulmányokat folytató brazil hallgatók megélhetési költségeinek ismertetésére kerül sor. A tudományos, szakmai munka színvonalának értékelése mellett fontos volt számunkra, hogy megismerjük, hogyan alakulnak a fiatalok megélhetési költségei, továbbá milyen kedvező multiplikátor hatásokkal számolhatunk.

A költségek elemzésén keresztül arra a kérdésre keressük a választ, hogy az ösztöndíj mennyiben fedezi a szükségleteket. Erre vonatkozóan a hallgatók szubjektív értékítéletére is rákérdeztünk. Abból indultunk ki, hogy a megélhetési költségek nagyságát, annak érzékelését jelentősen meghatározza, hogy előzetesen milyen elvárásokkal érkeztek, melyek voltak azok az információk, amelyek alapján pénzügyi lehetőségeiket feltérképezték, meghatározták.

Modellünkben azzal a feltételezéssel éltünk, hogy amikor a hallgatók a külföldi továbbtanulás mellett döntenek, mérlegelik az oktatásba fektetett költségek megtérülését. A geopolitikai térség választását követően az ország választásában szerepet játszik az oktatási és megélhetési költségek várható alakulása, vagy esetlegesen a kínált ösztöndíjlehetőségek.

\footnotetext{
2 Leuveni nyilatkozat: 2009. április 29-én 46 ország oktatási miniszterei nyilatkozatukban is megerősítették azon szándékukat, hogy egy olyan Felsőoktatási Térség létrehozásán fáradoznak, amely képes az új kihívásokra, a megváltozott gazdasági körülményekre hatékonyan és gyorsan reagálni. Az élethosszig tartó tanulás, a nemzetközi nyitottság és mobilitás, a hallgató központú tantervi reform, a munkaadók igényeinek figyelembe vétele, szakmai gyakorlat támogatása, az egyenlő esélyek biztosítása a minőségi felsőoktatásban való részvételhez, az oktatás-kutatás-innováció megvalósulása, az átláthatóbb felsőoktatás, és az állami szerepvállalás-kontra külső finanszírozás szükségessége mellett foglaltak állást. Forrás: https://media.ehea.info/file/2009_Leuven_Louvain-la-Neuve/06/1/Leuven_Louvain-la-Neuve_Communique_April_2009_595061.pdf
} 
A hallgatók, amikor az oktatási és a megélhetési költségek várható alakulását számba veszik, a költségeket a saját hazájukban felmerülő költségekkel vetik össze. Amennyiben közel hasonlóak a költségtényezők, ebben az esetben a külföldi továbbtanulás mellett döntenek.

\section{ÁLTALÁNOS INFORMÁCIÓK}

A Tudomány Határok Nélkül program keretében a brazil kormány 100.000 hallgatónak tette lehetővé, hogy több mint 40 ország felsőoktatási intézményében folytathassák tanulmányaikat. A brazil hallgatók által elnyert ösztöndíjak számát tekintve Magyarország a ranglista 11. helyén áll. A három tanév során (2013/2014 - 2015/2016) összesen 2 187 fő brazil hallgató 18 magyarországi felsőoktatási intézményben folytatta tanulmányait.

A magyar fóvárosban (Budapesten) tanult a hallgatók közel 70 százaléka, míg 30 százalékuk vidéki egyetemeken. A legtöbb brazil hallgatót fogadó intézmények a Budapesti Müszaki és Gazdaságtudományi Egyetem (BME), amely összesen 795 fő (36,4\%), a Debreceni Egyetem, amely 220 fö (10,06\%), és az Eötvös Loránd Tudományegyetem (ELTE), amely 177 fó (8,09\%) hallgató képzését biztosította. Az intézmény választása a brazil hallgatók által előzetesen megjelölt preferencia sorrend alapján történt, jellemzően az első helyen megjelölt intézmény került elfogadásra.

\section{Nem, születési év, egyetem, képzési terület}

A kérdőív első része általános információkat tartalmazott, amely a nemre, a születési évre, az egyetemre, a képzési területre irányult.

A Tudomány Határok Nélkül programban részt vevők közül a legnagyobb arányban a Semmelweis Egyetemen (37\%), az Óbudai Egyetemen (35\%) és a Miskolci Egyetemen (33\%) tanulmányokat folytató hallgatók töltötték ki a kérdőívet. Átlag feletti (közel 30\%-os) volt a kitöltöttség a Budapesti Müszaki és Gazdaságtudományi Egyetemen (29\%), a Szegedi Tudományegyetemen (29\%) és az Eötvös Loránd Tudományegyetemen (28\%).

A képzési területet tekintve a müszaki tudományok (46,4\%), majd az orvos- és egészségtudományok $\quad(14,8 \%)$, továbbá az informatika $(11,4 \%)$ területeken tanulmányokat folytatók töltötték ki a legnagyobb arányban a kérdőívet, amely tükrözi az ösztöndíjprogramban részt vevők képzési területenkénti megoszlását.

A kitöltők nemenkénti megoszlását tekintve 65 százalékuk férfi, míg 35 százalékuk nő volt. A képzési területet és a nemenkénti megoszlást vizsgálva megállapítható, hogy az informatika, a müszaki, a természettudományi, valamint a müvészeti képzési területeken a férfiak dominálnak, 80-70-70-73 százalékos arányban. Az agrár, a gazdaságtudományok, az orvos- és egészségtudományok esetében a nemek közötti megoszlás egyenletesebb volt.

A hallgatók neme és a képzési terület választása közötti összefüggés vizsgálatára a Pearson-féle Khi-négyzet és a Cramer mutatót használtuk. A Pearson féle Khi négyzet $(\chi 2=30,268$; df $=6$; $\mathrm{p}=0,000)$ értéke 0,000 szignifikancia szintü. A valószínűségi arány (Likelihood Ratio) szintén hasonló a Khi-négyzetével (0,000 szignifikancia szintü). A Cramer V is szignifikáns $\left(0,231^{* * *}\right)$. Ennek eredményeként megállapítható, hogy erős pozitív kapcsolat figyelhető meg a hallgatók neme és a választott képzési terület között.

A képzési terület és az életkor megoszlását vizsgálva, az életkort tekintve nincs nagy szóródás, a mintába bevont hallgatók átlagéletkora 24,5 év volt.

\section{A KÖLTSÉGEK ELEMZÉSE}

A költségek alakulását ugyan fenntartással kell kezelni, mert erős szubjektivitást is tartalmazhat. Az adatokkal szemben támasztott mennyiségi és minőségi követelmények mellett került sor azok rendszerezésére. A kiugró értékek feltárása céljából a boksz-plot eljárást alkalmaztuk.

Az első kérdéskör az ösztöndíjra és a megélhetési költségekre vonatkozott. A brazil hallgatók átlagosan 600 EUR és 1000 EUR közötti havi ösztöndíj támogatásban részesültek. A továbbiakban a költségek elemzésén keresztül arra a kérdésre keressük a választ, hogy az ösztöndíj mennyiben fedezi a szükségleteket. Erre vonatkozóan a hallgatók szubjektív értékítéletére is rákérdeztünk. Abból indultunk ki, hogy a megélhetési költségek nagyságát, annak érzékelését jelentősen meghatározza, hogy előzetesen milyen elvárásokkal érkeztek, melyek voltak azok az ismeretek, amelyek alapján pénzügyi lehetőségeiket feltérképezték. A szubjektív értékítéletet erősen befolyásolja az adott ország gazdasági helyzete, azon belül is a válaszadó családi, társadalmi helyzete. Abban az esetben, amenynyiben az előzetes értesülések alapján úgy ítélték meg, hogy a fogadó országban kevesebb pénzből is meg lehet élni, ebben az esetben a megkérdezettek úgy vélekedtek, hogy a fogadó országban olcsóbb a megélhetés, mint saját hazájukban. 


\section{A megélhetési költségekre vonatkozó elözetes információk}

A megélhetési költségek tekintetében a hallgatók 50 százaléka (50,3\%) érezte úgy, hogy a megélhetési költségek az elözetes várakozásaik alapján alakultak (1. táblázat). További pozitívum, hogy több mint 40 százalékuk (40,7\%) esetében a megélhetési költségek alacsonyabbak voltak, mint amire számítottak. A költségek jelentőségét erősíti az a tény, hogy arra a kérdésre, hogy egy ország kultúrájának megismerését, a szerzett tapasztalatokat nem lehet számokban mérni, nem lehet a költségek felmerülésével párhuzamba állitani, a megkérdezetteknek csak 6 százaléka jelölte meg.

A hallgatók a megélhetési költségekről az információt az internetröl (55\%), a képzésben részt vevő diákoktól (16,5\%), barátoktól (11,6\%) szerezték be, vagyis előzetesen tájékozódtak. A két ország közötti gazdasági különbségek a hallgatói válaszokban is megjelentek, Magyarországon kedvezőbbek a megélhetési költségek, mint Brazíliában.

1. táblázat: A megélhetési költségekre vonatkozó elózetes információk - képzési területenként

\begin{tabular}{|l|c|c|c|}
\hline \multirow{2}{*}{ KÉPZÉSI TERÜLET } & \multicolumn{3}{|c|}{ MEGÉLHETÉSI KÖLTSÉGEK } \\
\cline { 2 - 4 } & $\begin{array}{c}\text { ELŐZETES ISME- } \\
\text { RETEIK SZERINT } \\
\text { ALAKULTAK } \\
\mathbf{( \% )}\end{array}$ & $\begin{array}{c}\text { MAGASABBAK } \\
\text { VOLTAK } \\
\text { (\%) }\end{array}$ & $\begin{array}{c}\text { ALACSONYABBAK } \\
\text { VOLTAK } \\
\text { (\%) }\end{array}$ \\
\hline Agrártudományok & 48,9 & 4,4 & 46,7 \\
\hline Gazdaságtudományok & 46,2 & 5,1 & $\mathbf{4 8 , 7}$ \\
\hline Informatika & $\mathbf{5 9 , 0}$ & 0,0 & 41,0 \\
\hline Müszaki & 51,6 & 1,6 & 46,8 \\
\hline Múvészet & 33,4 & $\mathbf{8 , 3}$ & $\mathbf{5 8 , 3}$ \\
\hline $\begin{array}{l}\text { Orvos- és egészségtu- } \\
\text { domány }\end{array}$ & $\mathbf{6 5 , 4}$ & 1,2 & 33,4 \\
\hline Természettudományok & $\mathbf{5 6 , 8}$ & 4,5 & 38,7 \\
\hline ÁTLAG: & $\mathbf{5 4 , 0}$ & 2,2 & 43,8 \\
\hline
\end{tabular}

Forrás: Kreditmobilitás kutatás 2016-2017. év. (Böcskei et al. 2018)

Összességében elmondható, hogy a hallgatók 54 százaléka esetében a várakoznak megfelelöen alakultak a megélhetési költségek, és közel 44 százalékukat $(43,8 \%)$ pozitív meglepetés érte, vagyis alacsonyabbak voltak a költségek, mint amire számítottak. Mindösszesen a mintába került hallgatók 2 százaléka $(2,2 \%)$ tartotta magasabbnak a megélhetést, elözetes várakozásaihoz képest.

Képzési területenként vizsgálva a megélhetési költségeket, az informatika, az orvos- és egészségtudományi, továbbá a természettudományi képzési területeken tanulmányokat folytatók leképezik az átlagot, vagyis többségük $(59,0 \% ; 65,4 \% ; 56,8 \%)$ úgy vélekedett, hogy a megélhetési költségek az elözetes ismereteik és várakozásaik szerint alakultak.
A gazdaságtudományok és a mủvészet képzés területeken tanulmányokat folytatók esetében viszont többségben voltak azok, akik a megélhetési költségeket alacsonyabbnak tartották, mint amire számítottak. Ugyanakkor a művészet képzés területén volt a legmagasabb azok aránya, akik magasabbnak tartották a megélhetési költségeket, mint ahogy azt előzetesen várták. A müvészeti képzés esetében, a kis elemszámra tekintettel, mindebből nem vonható le messzemenő következtetés. 
2. táblázat: A megélhetési költségekre vonatkozó előzetes információk - intézményenként

\begin{tabular}{|c|c|c|c|}
\hline \multirow[b]{2}{*}{ INTÉZMÉNYEK } & \multicolumn{3}{|c|}{ MEGÉLHETÉSI KÖLTSÉGEK ALAKULÁSA } \\
\hline & $\begin{array}{c}\text { ELŐZETES ISMERE- } \\
\text { TEIK SZERINT ALA- } \\
\text { KULTAK } \\
(\%)\end{array}$ & $\begin{array}{l}\text { MAGASABBAK } \\
\text { VOLTAK } \\
(\%)\end{array}$ & $\begin{array}{c}\text { ALACSONYAB- } \\
\text { BAK } \\
\text { VOLTAK } \\
(\%) \\
\end{array}$ \\
\hline $\begin{array}{l}\text { Budapesti Corvinus Egye- } \\
\text { tem (BCE) }\end{array}$ & 42,1 & 0,0 & 57,9 \\
\hline $\begin{array}{l}\text { Budapesti Gazdasági } \\
\text { Egyetem (BGE) }\end{array}$ & 47,4 & 5,3 & 47,4 \\
\hline $\begin{array}{l}\text { Budapesti Mủszaki és } \\
\text { Gazdaságtudományi Egye- } \\
\text { tem (BME) }\end{array}$ & 54,0 & 0,9 & 45,1 \\
\hline Debreceni Egyetem (DE) & 67,5 & 0,0 & 32,5 \\
\hline $\begin{array}{l}\text { Dunaújvárosi Egyetem } \\
\text { (DUE) }\end{array}$ & 46,7 & 13,3 & 40,0 \\
\hline $\begin{array}{l}\text { Eszterházy Károly Egye- } \\
\text { tem (EKE) }\end{array}$ & 100,0 & 0,0 & \\
\hline $\begin{array}{l}\text { Eötvös Loránd Tudomány- } \\
\text { egyetem (ELTE) }\end{array}$ & 63,0 & 2,2 & 34,8 \\
\hline $\begin{array}{l}\text { Gábor Dénes Főiskola } \\
\text { (GDF) }\end{array}$ & 50,0 & 0,0 & 50,0 \\
\hline Miskolci Egyetem (ME) & 50,0 & 0,0 & 50,0 \\
\hline $\begin{array}{l}\text { Metropolitan Egyetem } \\
\text { (METU) }\end{array}$ & 0,0 & 0,0 & 100,0 \\
\hline $\begin{array}{l}\text { Magyar Képzőmúvészeti } \\
\text { Egyetem (MKE) }\end{array}$ & 33,3 & 8,3 & 58,3 \\
\hline $\begin{array}{l}\text { Nyugat-Magyarországi } \\
\text { Egyetem (NyME) }\end{array}$ & 100,0 & 0,0 & \\
\hline Óbudai Egyetem (OE) & 45,5 & 2,3 & 52,3 \\
\hline Pannon Egyetem (PE) & 25,0 & 0,0 & 75,0 \\
\hline $\begin{array}{l}\text { Pécsi Tudományegyetem } \\
\text { (PTE) }\end{array}$ & 64,3 & 7,1 & 28,6 \\
\hline $\begin{array}{l}\text { Semmelweis Egyetem } \\
\text { (SE) }\end{array}$ & 70,0 & 0,0 & 30,0 \\
\hline $\begin{array}{l}\text { Szent István Egyetem } \\
\text { (SZIE) }\end{array}$ & 50,0 & 5,3 & 44,7 \\
\hline $\begin{array}{l}\text { Szegedi Tudományegye- } \\
\text { tem (SZTE) }\end{array}$ & 33,3 & 8,3 & 58,3 \\
\hline ÖSSZESEN: & 54,0 & 2,3 & 43,8 \\
\hline
\end{tabular}

Forrás: Kreditmobilitás kutatás 2016-2017. év. (Böcskei et al. 2018) 
Intézményi vonatkozásban a Dunaújvárosi Egyetemen tanulók voltak azok, akik messzemenően eltértek az átlagtól, magasabbnak értékelték a költségeket, mint ahogy arra előzetesen számítottak (2. táblázat). A vidéki egyetemek vonatkozásban az Eszterházy Károly Egyetem, a Nyugat-Magyarországi Egyetem és a Debreceni Egyetem hallgatói voltak azok, akik előzetesen kiválóan tájékozódtak (vagy kaptak tájékoztatást) a költségekröl. A főváros vonatkozásában a Semmelweis Egyetem hallgatói voltak azok, akikről elmondható, hogy elözetes ismereteik szerint alakultak a költségeik (70,0\%).

A Metropolitan Egyetem, a Magyar Képzőmüvészeti Egyetem, a Pannon Egyetem és a Szegedi Tudományegyetem hallgatói esetében viszont még kedvezőbben alakultak a megélhetési költségek, mint amire számítottak.

A föváros és a vidéki egyetemek közötti eltérö megélhetési költségek a brazil hallgatók válaszaiban nem rajzolódtak ki egyértelmüen. Ennek okát elsősorban abban látjuk, hogy szinte valamennyi megkérdezett hallgató esetében az ösztöndíj fedezte a költségeket, így finanszírozási nehézségekkel nem kellett számolniuk. Másrészt a világháló adta tájékozódási lehetőségnek köszönhetően jól mérték fel a megélhetéssel járó kiadásaikat. Harmadrészt vélelmezhetö, hogy igen erős a Brazíliából érkezett hallgatók közötti kapcsolat, így a közös hétvégi programok, a fővárosba való utazások révén kiegyenlítődnek az esetleges különbségek. Ahhoz, hogy feltevésünk bizonyosságot nyerjen, ehhez a továbbiakban szociológiai kutatásokra lenne szükség.

A megélhetési költségek nemenkénti megoszlást vizsgálva megállapítható, hogy a nők közel 60 százaléka (59,1\%) esetében a költségek az előzetes ismeretek, várakozások szerint alakultak. Vélelmezhető, hogy a női hallgatók a várható kiadásaikat alaposabban átgondolják, mint a férfiak. A hallgatók neme és a megélhetési költségekkel szembeni előzetes várakozások összefüggésének vizsgálatára a Pearson-féle Khi-négyzet és a Cramer mutatót használtuk. A Pearson féle Khi négyzet $(\chi 2=5,069$; $\mathrm{df}=2 \mathrm{p}=0,079$ ) értéke 0,079 szignifikancia szintü. A valószínűségi arány (Likelihood Ratio) szintén hasonló a Khi-négyzetével (0,080 szignifikancia szintü). A Cramer V gyengén ugyan, de szignifikáns $\left(0,098^{*}\right)$. Ennek eredményeként megállapítható, hogy kimutatható egy gyenge kapcsolat a hallgatók neme és a költségek elözetes várakozása között.

\section{Megélhetési költségek a fogadó országban és a szülőhazában}

A megélhetési költségek esetében mind a fogadó országban, mind pedig a saját szülőhazájukban felmerült költségekre - azok tételes megoszlására is - rákérdeztünk. Módszertani szempontból fontosnak tartjuk megemlíteni, hogy az egyes megélhetési költségek meghatározásakor a válaszadóknak egy 10 fokozatú értékhatár skál alapján kellett megitélniük kiadásaikat.

A hallgatók több mint fele 300 és 600 EUR közé becsülte a havi költségeit, míg közel 40 százalékuk 600 és 1000 EUR közé. A két értékhatár alatt és felett költekezők a minta 2-3 százalékát tették ki. Az értékadatok összhangban vannak a hallgatók azon megállapításával, amely szerint költségeiket a válaszadók több mint 95 százaléka - ösztöndíjból finanszírozták (3. táblázat).

\section{3. táblázat: Megélhetési költségek kereszttáblája, adatok \%-ban megadva}

\begin{tabular}{|l|c|c|c|c|c|}
\hline $\begin{array}{l}\text { MEGÉLHETÉSI } \\
\text { KÖLTSÉGEK }\end{array}$ & \multicolumn{5}{|c|}{ SZÜLŐHAZÁBAN } \\
\hline $\begin{array}{l}\text { FOGADÓ } \\
\text { ORSZÁGBAN }\end{array}$ & $\begin{array}{c}\text { költség }< \\
299 \text { EUR }\end{array}$ & $\begin{array}{c}300 \text { EUR }< \\
\text { költség } \\
>599 \text { EUR }\end{array}$ & $\begin{array}{c}600 \text { EUR }<\text { költség } \\
>999 \text { EUR }\end{array}$ & $\begin{array}{c}1000 \text { EUR }< \\
\text { költség } \\
>1 \text { 499 EUR }\end{array}$ & Összesen \\
\hline költség <299 EUR & $\mathbf{1 4 , 3}$ & 50,0 & 35,7 & 0,0 & 100,0 \\
\hline $\begin{array}{l}300 \text { EUR }<\text { költség }>599 \\
\text { EUR }\end{array}$ & 7,6 & $\mathbf{4 6 , 9}$ & 36,0 & 9,5 & 100,0 \\
\hline $\begin{array}{l}\text { 600 EUR }<\text { költség }>999 \\
\text { EUR }\end{array}$ & 1,5 & 26,3 & $\mathbf{5 9 , 5}$ & 12,7 & 100,0 \\
\hline $\begin{array}{l}1000 \text { EUR }<\text { költség }>1 \\
499 \text { EUR }\end{array}$ & 0,0 & 33,3 & 27,8 & $\mathbf{3 8 , 9}$ & 100,0 \\
\hline ÖSSZESEN: & 5,2 & 38,7 & 44,6 & 11,5 & 100,0 \\
\hline
\end{tabular}

Forrás: Kreditmobilitás kutatás 2016-2017. év. (Böcskei et al. 2018) 
A kereszttábla átlójában elhelyezkedő százalékos arányok mutatják, hogy a hallgatók hány százaléka számolt ugyanakkora költséggel a fogadó országban, mint saját hazájában. A kereszttábla átlójától lefelé található százalékos értékek pedig azt mutatják, hogy a válaszadók hány százaléka az, akik számára a külföldi megélhetés (tanulás) magasabb költségeket jelentett.

A kereszttábla átlójától felfelé mutató százalékos értékek arról adnak tájékoztatást, hogy a válaszadók hány százaléka vélekedik úgy, hogy a fogadó országban kevesebbet költenek, mint saját hazájukban, vagyis a fogadó ország olcsóbb megélhetést biztosit számukra.

Azon hallgatók, akik például a fogadó országban 300 és 599 EUR közötti megélhetési költség- gel számoltak, azok 46,9 százaléka otthon is ennyit költ(ene), míg 36 százalékuk otthon magasabb, vagyis 600 és 999 EUR közötti költséggel számol, míg közel 10 százalékuk még ennél is magasabb, 1000 és 1499 EUR közötti költséggel tervez.

A megélhetési költségek alakulása - a fogadó országban és a szülőhazában - közötti összefüggés vizsgálatára a Pearson-féle Khi-négyzet és a Cramer mutatót használtuk. A Pearson féle Khi négyzet $(\chi 2=57,192 ; \mathrm{df}=9 \mathrm{p}=0,000)$ értéke 0,000 szignifikancia szintü. A valószínüségi arány (Likelihood Ratio) szintén hasonló a Khi-négyzetével (0,000 szignifikancia szintű). Ennek eredményeként megállapítható, hogy erős összefüggés mutatható ki a két változó között.

4. táblázat: Megélhetési költségek alakulása átlag, móduszok minimum és maximum értékei, EUR-ban megadva

\begin{tabular}{|c|c|c|c|c|}
\hline MEGÉLHETÉSI KÖLTSÉGEK & ÁTLAG & MINIMUM & MAXIMUM & $(\%)$ \\
\hline Szállás (bérelt lakásban) & 230 & 200 & 249 & 31,5 \\
\hline Szállás (kollégiumban) & $(120)$ & 120 & 159 & 50,0 \\
\hline Étkezés & 132 & 80 & 119 & 33,2 \\
\hline Közlekedési költség (helyi) & 20 & 1 & 19 & 65,0 \\
\hline Higiénia & 40 & 20 & 49 & 46,5 \\
\hline Ruhavásárlás & 57 & 50 & 79 & 36,1 \\
\hline $\begin{array}{l}\text { Tanulmányokhoz szükséges könyv, } \\
\text { füzet stb }\end{array}$ & 29 & 20 & 49 & 45,3 \\
\hline Egyéb könyv, füzet stb. & 18 & 1 & 19 & 50,4 \\
\hline Müszaki cikkek vásárlása & 32 & 20 & 49 & 30,4 \\
\hline $\begin{array}{l}\text { Sportolási költségek (uszoda, kon- } \\
\text { diterem) }\end{array}$ & 17 & 20 & 49 & 42,8 \\
\hline Mozi & 11 & 1 & 19 & 56,6 \\
\hline Színház & 7 & 0 & 0 & 49,6 \\
\hline Kirándulás (a fogadó országban) & 43 & 20 & 49 & 36,3 \\
\hline $\begin{array}{l}\text { Kirándulás (a fogadó országon } \\
\text { kívül) }\end{array}$ & 116 & 120 & 159 & 41,9 \\
\hline $\begin{array}{l}\text { Egyetemi rendezvényeken való } \\
\text { részvétel költsége }\end{array}$ & 6 & 0 & 0 & 61,0 \\
\hline $\begin{array}{l}\text { Egyéb rendezvényeken való rész- } \\
\text { vétel (pl. koncertek) }\end{array}$ & 13 & 0 & 0 & 46,2 \\
\hline ÖSSZESEN: & $(660) / 770$ & $(473) / 553$ & $(818) / 908$ & - \\
\hline
\end{tabular}

Megjegyzés: A táblázat utolsó oszlopa a móduszokhoz tartozó megoszlás százalékos értékét mutatja. Forrás: Kreditmobilitás kutatás 2016-2017. év. (Böcskei et al. 2018) 


\section{Megélhetési költségek alakulása}

A költségek elemzése számos szubjektív tényezőt tartalmaz, azonban arányaiban valós információt szolgáltat a hallgatók költekezési szokásairól. Az egyes költségtételek móduszainak - a kérdőívben megadott - intervallum értékeivel számolva megkapjuk a minimum és maximum költségeket. Ezen számítás alapján átlagosan havonta 553 és 908 EUR (kollégista esetében 473 és 818 EUR) között költekeznek a hallgatók. Ezen értékadat releváns a korábbi válaszokban kapott értékekkel (4. táblázat).

A megélhetési költségek tekintetében tételesen is vizsgáltuk a hallgatók költési preferenciát. A tételes költségek átlagértékei alapján a hallgatók megélhetési költsége 770 EUR (amennyiben nem kollégista, mert ez utóbbi esetben 660 EUR), amely összhangban van a hallgatók által korábban adott válaszokkal, amely során meg kellett becsülniük havi kiadásaikat.

A hallgatók költségstruktúrájában jelentős tételként jelent meg a szállásköltség, ugyanis többségük bérelt lakásban (és nem kollégiumban) élt. $\mathrm{Az}$ átlagos egyetemisták életét élve költekeznek, a szabadidő aktív eltöltésére is áldoznak. Mind a fogadó országban, mind azon kívül kirándulásokat szerveznek.

A hallgatók megélhetési költségeit tekintve a szállásra, kirándulásokra és az étkezésre fordítják a legtöbb összeget. A kapott ösztöndíj jelentős részét elsősorban a fogadó országban költik el, a magas szállásdíj és a jelentős étkezési költségeknek köszönhetően elsősorban adott térségben (egyetemi városban). A hallgatók nem elszigetelten, nem magányosan élik meg a fogadó országban eltöltött hónapokat, hanem társaságban, barátokkal. Társadalmi kapcsolataikra elsősorban az anyaországi és az egyetemi társakhoz való kötödés a jellemzö. A nagyvárosok szórakozóhelyei által nyújtott lehetőségek az egyetemi élet egy másik oldala. A külföldi hallgatók - elsősorban a kreditképzésben részt vevők - a városból, az országból „mindent látni” szeretnének, így ők azok, akik a tanulmányok alatt is igénylik az aktív szórakozási lehetöségeket.

Az utazást kedvelő hallgatók elsősorban az ország fővárosát és turisztikai központját választották elsődleges desztinációként. Budapestet követően a kulturális és történelmi jelentőségü, valamint a kulináris élvezeteket nyújtó vidéki nagyvárosok a legkedveltebb úti célok. A városok kiválasztásában szerepet kapnak az egyetemek által szervezett tanulmányi programok, a hallgatók és baráti társaságok érdeklődési köre, valamint a magyar diákok (mentorok) által tett javaslatok is.
A hallgatók közel 80 százaléka (78,3\%) fogad vendégeket a tanulmányai alatt, a szüken vett család mellett a barátaikat is meghívják a fogadó országba. A fogadó ország nevezetességeinek megismerése mellett szívesen ismerkednek a környező országok kulturális adottságaival is. Így a nemzetközi hallgatói mobilitás multiplikátor hatásai az idegenforgalmi ágazatban is megjelennek, miután a második legmagasabb költségtényező a kirándulásokra fordított összeg.

A külföldi fiatalok többsége Magyarország geopolitikai helyzetét emelte ki, ugyanis kiváló lehetőséget nyújt arra, hogy a környező európai országokat is megismerjék. A kedvezö utazási lehetőségeket kihasználva, szomszédos országaink is kedvelt úti célok. A karácsonyi bécsi vásár számos hallgatót vonz Ausztriába, de történelmi, építészeti remekeivel és sajátos hangulatával szintén kedvelt kirándulóhely Szlovákia, Csehország, Németország, Lengyelország és Szlovénia is. A hallgatók viszonylag nagy számban szerveznek önálló ország és városlátogatásokat is, így Franciaország és Olaszország is nagy népszerüségnek örvend.

A látogatások motivációjaként a fentebb említetteken kívül baráti és/vagy családi látogatások, turisztikai szempontok és nemzetközi eseményeken való részvétel kerültek említésre.

Külön vizsgáltuk, hogy van-e összefüggés a hallgatók kiadásai és a képzési terület között, azonban egy-egy esetet leszámítva nincs szignifikáns kapcsolat.

\section{Megélhetési költségek finanszírozása}

A finanszírozási kérdések egyik sarkalatos pontja, hogy mennyiben elegendő az ösztöndíj, mennyiben fedezi a megélhetést, milyen egyéb forrásokat kell igénybe venniük (5. táblázat). A válaszadók több mint 95 százaléka (95,4\%) az ösztöndíjból fedezi költségeit, és igen kis százalékban támaszkodnak szülöi segítségre és diákhitelre. 
5. táblázat: Megélhetési költségek finanszírozása

\begin{tabular}{|l|c|c|c|c|}
\hline $\begin{array}{l}\text { MEGÉLHETÉSI KÖLTSÉ- } \\
\text { GEK FINANSZÍROZÁSA }\end{array}$ & $\begin{array}{c}\text { FREQUENCY } \\
\text { (FŐ) }\end{array}$ & $\begin{array}{c}\text { PERCENT } \\
\text { (\%) }\end{array}$ & $\begin{array}{c}\text { VALID } \\
\text { PERCENT } \\
\text { (\%) }\end{array}$ & $\begin{array}{c}\text { CUMULATIVE } \\
\text { P. } \\
\text { (\%) }\end{array}$ \\
\hline $\begin{array}{l}\text { Valamennyi költségemet az } \\
\text { ösztöndíj fedezi }\end{array}$ & 541 & 95,2 & $\mathbf{9 5 , 4}$ & 95,4 \\
\hline Szüleim finanszírozzák & 16 & 2,8 & 2,8 & 98,2 \\
\hline $\begin{array}{l}\text { Szüleim anyagi segítsége mellett } \\
\text { a diákhitelt is felvettem }\end{array}$ & 2 & 1,4 & 1,4 & 99,6 \\
\hline ÖSSZESEN: & 567 & 100.0 & 100,0 & \\
\hline
\end{tabular}

Forrás: Kreditmobilitás kutatás 2016-2017. év. (Böcskei et al. 2018)

\section{ÖSSZEFOGLALÁS}

A Tudomány Határok Nélkül program nem csak a brazil hallgatók számára volt sikeres, de az egész magyar felsőoktatás számára is. A program lehetőséget adott arra, hogy megismerjük, hogy külföldi továbbtanulás esetén a képzés megtérülése, a megélhetési költségek mennyiben játszanak meghatározó szerepet. Kutatási eredményeink alátámasztották feltételezésünket, amely szerint a hallgatók prioritásként kezelik, hogy kedvezőbb anyagi feltételekkel tudjanak tanulni, így a képzés választásában szerepe volt az ösztöndíj lehetőségének, továbbá a megélhetési költségeknek.

A költségek elemzésén keresztül választ kaptunk arra a kérdésre is, hogy a hallgatók számára nyújtott ösztöndíj fedezetet teremt-e szükségleteik kielégítésére.

A fiatalok számára a tanulás mellett a színesebb és gazdagabb egyetemi hallgatói élet, egymás kultúrájának mélyebb megismerése is fontos szempontként jelenik meg. A külföldi hallgatók szívesen kirándulnak, hívják meg barátaikat egy-egy hétvégére, amennyiben tartalmas programokat tudunk kínálni részükre. Ebben az egyetemeknek, a városnak, a tágabb környezetnek is együtt kell működnie.

A külföldi hallgatók Magyarországot az egyik legszebb európai országnak tartják, páratlan kulturális, természeti adottságaival, köztük a Dunakanyar, Budapest és a Balaton szépségeivel együtt. A külföldiek számára akkor leszünk kedvelt egyetemi és turisztikai célpont, ha szolgáltatásainkat folyamatosan fejlesztjük. Az éjjel-nappal nyitva tartó üzletek, kereskedelmi és vendéglátó egységek mellett ugyan olyan fontos az angol nyelven való kommunikáció biztosítása.

A megélhetési költségeket nem szabad elszigetelten vizsgálni, ugyan ilyen fontos tényezö, hogy megismerjük a külföldröl érkezők elvárásait, oktatási rendszerünk erősségeit, továbbá azokat a kihívásokat, amelyek megoldásra várnak. Kutatási eredményeink alapján megállapítható, hogy a hallgatók egy olyan befogadó és biztonságos országban szeretnek tanulni és nemzetközi tapasztalatokat szerezni, amely a későbbi karrierjük szempontjából meghatározó lehet. Kiemelten fontos volt számukra az akadémiai háttér megléte, a kutatásokba való bekapcsolódás lehetősége. Prioritásként jelent meg a multikulturális társadalmi környezethez való tartozás és alkalmazkodás, a határok nélküli, nemzetközi térben való mozgás is.

A diákok mobilitási igénye egyre növekszik, ugyanis a piac elismeri a nemzetközi tapasztalatokat (Jones 2010). A gazdasági (politikai) kapcsolatok is egyre nagyobb súllyal játszanak szerepet. A nagyvállalatok jelenléte az adott térségben a fiatalok számára is egy közvetlen kapcsolatot jelent(het), amely esetlegesen későbbi karrierjük kibontakozására hatással lehet.

Kutatási felmérések a nemzetköziesedés legfőbb gátjaként a nem megfelelő idegen nyelv-tudás mellett a pénzhiányt emelték ki, mint megoldandó problémát (Lannert 2018). A Tudomány Határok nélkül ösztöndíjprogram mintaként szolgálhat ahhoz, hogy egy-egy kormány oktatáspolitikája mennyiben mérsékelheti a finanszírozási gondok kérdését.

A másik oldalról, mint fogadó ország, kérdésként merül fel, hogy a magyarországi felsőoktatási intézmények mennyiben feleltek meg a hallgatói elvárásoknak? Talán minden elemzésnél többet mond, hogy a hallgatók közel 98 százaléka a tanulmányok befejezését követően is vissza szeretne térni Magyarországra, egyrészt egy újabb szemeszterre, másrészt esetlegesen egy újabb diploma megszerzésének reményében, vagy „csak” látogatóba, turistaként. 


\section{TOVÁBBI LEHETSÉGES KUTATÁSI IRÁNYOK}

A magyar kormány komoly erőfeszítéseket tesz annak érdekében, hogy minél több külföldi hallgató számára tegye vonzóvá felsőoktatási intézményeit. A képzések jellemzően fizetősek, azonban az önköltséges képzések mellett a tehetséges külföldi hallgatók részére különböző ösztöndíjprogramokat is kínál. Ugyanakkor jogos kérdésként merül fel, hogy ott, ahol az adott ország hallgatói számára is korlátozott az ösztöndíjjal való továbbtanulás lehetősége, mennyiben biztosítható a külföldi hallgatók támogatása.

Elsőként érdemes tisztázni, hogy csak a legkiválóbbak számára adatik meg, hogy a magyar állam ösztöndíjasa lehessen. A kiválóságok emelik az intézmény, az ország hírnevét, új sikeres kutatási eredményekhez járulhatnak hozzá, amely kiváló befektetés lehet. Másrészt az oktatás, a tudomány mellet épp oly fontos a magyar értékek, a kultúra megismertetése, amely egyúttal elősegíthetik a szélesebb társadalmi kapcsolatok kiépítését, nem csak Európában, de a világ többi országában is. Ma már egy térség, egy ország gazdasági fejlödéséhez nélkülözhetetlenek a különböző országok közötti gazdasági, társadalmi kapcsolatok, és különösen igaz ez, egy kis közép-kelet európai ország esetében. Az oktatás finanszírozása a világ valamennyi országába egy hosszú távú befektetés, amelynek megtérülése csak számokban nem, vagy legalábbis nehezen mérhető. A nemzetközi mobilitásban rejlő lehetőségek kiaknázása, a tudás, a készségek, az interkulturális és nyelvi kompetenciák fejlesztése, a felsőoktatás minőségének előmozdítása a magyar kormány kiemelt stratégiai programja. Ezen stratégiai program része a "keleti és a déli nyitás” néven meghirdetett, 2013-ban alapított Stipendium Hungaricum ösztöndíjprogram, amelynek fő célkitüzése, hogy a külföldi hallgatók számának növelésével népszerüsítse a versenyképes magyar felsőoktatást (Hangyál - Kasza 2018).

Jellemzően ma még versenyről, gazdasági haszonról beszélünk, amikor egy-egy fogadó ország, és/vagy felsőoktatási intézmény a különböző nemzetek hallgatóit fogadja. Azonban a nemzetköziesedésnek egy olyan kölcsönös együttmüködés alapjait kell megteremtenie, amely mindkét fél számára egy nyert-nyert helyzetet teremt. A pénzben mérhető profiton túl a nemzetközi mobiltás- nak sokkal nagyobb értéket kell, hogy képviseljen. Olyan értékeket, amelyek pusztán számokban nem mérhetők, mint:

- nyitottságot és megértést a különböző kultúrák megismerése révén,

- kritikus gondolkodásmód kialakítását

- készségek fejlődését.

Számos kutató megállapításával egyetértünk, amely szerint a külföldi tanulmányok választása egy igen összetett folyamat és számos tényező befolyásolja a döntéshozatalt. Az egyik legismertebb Mazzarol és Soutar által is említett „push and pull" modell, amely során vizsgálták, hogy a hazai környezetnek vagy a fogadó országnak van nagyobb súlya a döntés meghozatalában (Mazzarol \& Soutar 2002)

Ugyanakkor ezen tényezők mellett ugyan olyan fontos a mikroszintủ mobilitási folyamatok, továbbá a hallgatók személyes tulajdonságainak a vizsgálata is (Lee 2014, Wilkins et al. 2012, Li \& Bray 2007, Ahmad \& Hussain 2017). Így a hallgatói mobilitás mozgatórugóinak feltérképezése a továbbiakban is számos kutatási területnek adhat teret.

\footnotetext{
3 Mazzarol és Soutar szerint a kettő kombinációja (push and pull) a meghatározó, nem lehet csak az egyik, vagy a másik hatást figyelembe venni. A „Push and pull” modellt, mint kifejezést Lee használta először „A migráció elmélete” c. írásában (Lee, 1966).
} 


\section{HIVATKOZÁSOK}

Ahmad, S. Z., Hussain, M. (2017), ”An investigation of the factors determining student destination choice for higher education in the United Arab Emirates", Studies in Higher Education, 42 7, 1324-43 DOI: http://dx.doi.org/10.1080/0 3075079.2015.1099622

Börjesson, M. (2017), The global space of international students in 2010, Journal of Ethnic and Migration Studies 1256-75

Brooks, R., Waters J. (2011), Student Mobilities, Migration and the Internationalization of Higher Education. Basingstoke: Palgrave Macmillan

Böcskei E. - Bács Z. - Kovács B. - Tarnóczi T. - Fenyves V. (2018): Kreditmobilitás kutatási anyag 2016-2017. év.

Hangyál Zs. - Kasza G. (2018), Stipendium Hungaricum ösztöndijas hallgatók helyzete, véleménye, elvárásai, Tempus Közalapítvány, Budapest 1-21

Hetesi E. - Kéri A. (2018), „Miért jönnek Magyarországra és mit várnak tőlünk a külföldi hallgatók? Magyarországon tanuló külföldi hallgatók motivációi és elvárásai”, Marketing \& Menedzsment, 57 1 47-65

Jones, G. (2010), "Managing student expectation: The impact of top-up tuition fees", Perspectives, 14 2, 44-8

Lannert J. (2018), Nemzetközi hallgatók a hazai felsőoktatási intézményekben Tempus Közalapítvány, Budapest 1-31

Lee, E. S. (1966), ”A theory of migration", Demography, 3 1, 47-57

Li, M., Bray M. (2007), "Cross-Border Flows of Students for Higher Education: Push-Pull Factors and Motivations of Mainland Chinese Students in Hong Kong and Macau". Higher Education, 53 6, 791-818 DOI: https://doi. org/10.1007/s10734-005-5423-3.

Leung, M.: (2013), ’Read ten thousand books, walk ten thousand miles': Geographical mobility and capital accumulation among Chinese scholars", Transactions of the Institute of British Geographers, 38 2,:311-24
Mazzarol, T., Soutar, G. N. (2002), ”Push-pull factors influencing international student destination choice", International Journal of Educational Management, 16 2, 82-90

Wilkins, S., Balakrishnan, M., Huisman, J. (2012), "Student Choice in Higher Education: Motivations for Choosing to Study at International Branch Campus", Journal of Studies in International Education, 16 5, 413-33

Magyar Rektori Konferencia adatbázisa (kutatási célokra kikért adatbázis 2013-2015)

http://www.bologna-bergen2005.no/Docs/00 Main doc/990719BOLOGNA DECLARATION.PDF

https://www.ehea.info/pid34363/ministerial-declarations-and-communiques.html

https://media.ehea.info/file/2009_Leuven_Louvain-la-Neuve/06/1/Leuven_Louvain-laNeuve_Communique_April_2009_595061.pdf http://www.ond.vlaanderen.be/hogeronderwijs/ bologna/links/National-reports 
Dr. habil. Fenyves Veronika PhD, tanszékvezető egyetemi docens fenyves.veronika@econ.unideb.hu

Debreceni Egyetem Controlling Tanszék

Dr. Kovács Barnabás, kutatási igazgató info@etoki.hu Európai Tudományos Oktatási és Kutatási Intézet

Dr. habil. Böcskei Elvira PhD, egyetemi docens dr.bocskei.elvira@gmail.com

Budapesti Múszaki és Gazdaságtudományi Egyetem Gazdaság- és Társadalomtudományi Kar

Pénzügyek Tanszék

\section{The strategy of the cost-benefit principle The Science Without Borders - Brazil students in Hungary}

\section{THE AIMS OF THE PAPER}

The Brazilian government established the Science Without Borders scholarship programme, in the scope of which it was allowed for students to study for a year at foreign universities. Hungary was the first of the Central European countries to join the programme, thus the offer of Hungarian higher education institutions appeared alongside the offers of the universities of the largest countries. With regard to the future, we found it important to learn how foreign people see us Hungarians, what they think about our education system, to what extent the structure and standards of our education complies with international expectations, what our strengths are, and which areas that still face a number of challenges.

\section{METHODOLOGY}

The first part of the study introduces the Science Without Borders scholarship programme. Then, in the course of the scientific literature review, the main attributes of the three poles of international student mobility - the Pacific, Iberian and Central European poles - are discussed. Following the introduction of the topics of the questionnaire survey, the obtained findings will be presented. The questionnaire was processed through an SPSS-based statistical data analysis.

\section{MOST IMPORTANT RESULTS}

The present article describes the cost of subsistence of Brazilian students who pursue their higher education studies in Hungary. Through the analysis of costs, we managed to answer the question whether the scholarship provided to students covered all of their needs. Our research results supported our hypothesis according to which students prioritize their ability to study under more favourable financial circumstances, thus potential scholarships and the amount of living costs played an important role in the choice of the given training.

\section{RECOMMENDATIONS}

Financing education is a long-term investment in all countries of the world; its return is not quantifiable, or at least difficult to be measured through numbers. Beyond financially measurable profits, international mobility must represent much greater values, such as openness and understanding through becoming familiar with various cultures, development of critical thinking, and the improvement of skills. The choice of studying abroad is a very complex process, thus mapping the motivations behind student mobility will continue to open up numerous areas of research in the future.

Keywords: student mobility, higher education, Science Without Borders program, international scholarship program, subsistence costs 